\title{
Intra-Specific Variation Reveals Potential for Adaptation to Ocean Acidification in a Cold-Water Coral from the Gulf of Mexico
}

\author{
Melissa D. Kurman ${ }^{1 * t}$, Carlos E. Gómez ${ }^{1}$, Samuel E. Georgian ${ }^{2}$, Jay J. Lunden ${ }^{3}$ and \\ Erik E. Cordes ${ }^{1}$ \\ ${ }^{1}$ Department of Biology, Temple University, Philadelphia, PA, USA, ${ }^{2}$ Marine Conservation Institute, Seattle, WA, USA, \\ ${ }^{3}$ Department of Biological Sciences, Lock Haven University of Pennsylvania, Lock Haven, PA, USA
}

\section{OPEN ACCESS}

Edited by:

Iris Eline Hendriks,

University of the Balearic Islands,

Spain

Reviewed by:

Riccardo Rodolfo Metalpa Institut de Recherche Pour le

Développement (IRD), France

Dick Van Oevelen,

Royal Netherlands Institute for Sea

Research (NWO), Netherlands

*Correspondence:

Melissa D. Kurman

melissa.kurman.819@my.csun.edu

${ }^{\dagger}$ Present Address:

Melissa D. Kurman,

California State University, Northridge, Northridge, CA, USA

Specialty section:

This article was submitted to Global Change and the Future Ocean, a section of the journal Frontiers in Marine Science

Received: 30 October 2016 Accepted: 05 April 2017 Published: 04 May 2017

Citation:

Kurman MD, Gómez CE,

Georgian SE, Lunden JJ and Cordes EE (2017) Intra-Specific

Variation Reveals Potential for

Adaptation to Ocean Acidification in a Cold-Water Coral from the Gulf of

Mexico. Front. Mar. Sci. 4:111.

doi: 10.3389/fmars.2017.00111
Ocean acidification, the decrease in seawater $\mathrm{pH}$ due to the absorption of atmospheric $\mathrm{CO}_{2}$, profoundly threatens the survival of a large number of marine species. Cold-water corals are considered to be among the most vulnerable organisms to ocean acidification because they are already exposed to relatively low $\mathrm{pH}$ and corresponding low calcium carbonate saturation states $(\Omega)$. Lophelia pertusa is a globally distributed cold-water scleractinian coral that provides critical three-dimensional habitat for many ecologically and economically significant species. In this study, four different genotypes of $L$. pertusa were exposed to three $\mathrm{pH}$ treatments $(\mathrm{pH}=7.60,7.75$, and 7.90) over a short (2-week) experimental period, and six genotypes were exposed to two $\mathrm{pH}$ treatments $\mathrm{pH}=7.60$ and 7.90) over a long (6-month) experimental period. Their physiological response was measured as net calcification rate and the activity of carbonic anhydrase, a key enzyme in the calcification pathway. In the short-term experiment, net calcification rates did not significantly change with $\mathrm{pH}$, although they were highly variable in the low $\mathrm{pH}$ treatment, including some genotypes that maintained positive net calcification in undersaturated conditions. In the 6-month experiment, average net calcification was significantly reduced at low $\mathrm{pH}$, with corals exhibiting net dissolution of skeleton. However, one of the same genotypes that maintained positive net calcification $\left(+0.04 \%\right.$ day $\left.^{-1}\right)$ under the low $\mathrm{pH}$ treatment in the short-term experiment also maintained positive net calcification longer than the other genotypes in the long-term experiment, although none of the corals maintained positive calcification for the entire 6 months. Average carbonic anhydrase activity was not affected by $\mathrm{pH}$, although some genotypes exhibited small, insignificant, increases in activity after the sixth month. Our results suggest that while net calcification in L. pertusa is adversely affected by ocean acidification in the long term, it is possible that some genotypes may prove to be more resilient than others, particularly to short perturbations of the carbonate system. These results provide evidence that populations of $L$. pertusa in the Gulf of Mexico may contain the genetic variability necessary to support an adaptive response to future ocean acidification.

Keywords: Lophelia pertusa, climate change, deep sea, carbonic anhydrase, carbonate saturation 


\section{INTRODUCTION}

Climate change is dramatically altering the Earth's terrestrial and aquatic environments, with ocean acidification expected to elicit some of the more severe alterations to marine environments (Keeling et al., 1976; Parmesan and Yohe, 2003; Feely et al., 2004; Hoegh-Guldberg and Bruno, 2010). Carbon dioxide is currently being emitted into the atmosphere at a rate of approximately $49 \pm 4.5 \mathrm{Gt} \mathrm{CO}_{2}$ year $^{-1}$, and approximately one-third of these emissions are ultimately absorbed by the world's oceans (Sabine et al., 2004; IPCC, 2013). The absorption of this excess $\mathrm{CO}_{2}$ drives a series of chemical reactions that alter the carbonate chemistry of the seawater causing significant reductions in seawater $\mathrm{pH}$ and carbonate ion concentration $\left(\mathrm{CO}_{3}^{2-}\right)$ (Kleypas and Langdon, 2006). It is estimated that ocean $\mathrm{pH}$ will drop by $0.3-0.5 \mathrm{pH}$ units within the century, with estimates as high as $0.7 \mathrm{pH}$ units (Caldeira and Wickett, 2003). Consequently, ocean acidification lowers the saturation state $(\Omega)$ of calcium carbonate, such that some marine calcifiers are unable to maintain calcification rates that exceed dissolution, or do so at much greater energetic cost. This can compromise the biological and ecological functions of these species, including reduced extent and density of reef framework (Gattuso et al., 1998; Kleypas et al., 1999; Langdon and Atkinson, 2005), failed larval development (Kurihara, 2008), impairment of predator-prey interactions (Cripps et al., 2011; Gaylord et al., 2014), and changes in acid-base regulation (Pörtner et al., 2004).

Cold-water corals are one of the most important foundation species in the deep sea, providing habitat for a large number of associated species including many commercially important fish and invertebrates (Rogers, 1999; Roberts et al., 2006). In recent years, there has been great interest in predicting the physiological response of cold-water corals to future levels of ocean acidification, mainly because these species inhabit deepsea waters where aragonite saturation states $\left(\Omega_{\mathrm{ar}}\right)$ are naturally low, and thus will be experiencing corrosive waters sooner than shallow-water organisms (Orr et al., 2005; Guinotte et al., 2006). There is evidence that deep-sea corals in the Gulf of Mexico live close to the aragonite saturation horizon $\left(\Omega_{\mathrm{ar}} \sim 1\right)$ with $\left[\mathrm{CO}_{3}^{2-}\right.$ ] about $94 \mu \mathrm{mol} \mathrm{Kg}{ }^{-1}$ (Georgian et al., 2016a). Moreover, these species naturally exhibit slow growth and calcification rates, which range between $\sim 2$ to $9 \mathrm{~mm}_{\text {year }}{ }^{-1}$ (Brooke and Young, 2009; Larcom et al., 2014; Lartaud et al., 2014) making them particularly vulnerable to the effects of future ocean acidification. Nevertheless, recent evidence from experimental studies suggests that cold-water corals can be resistant to low aragonite saturation states, and may even be able to calcify in undersaturated conditions (Form and Riebesell, 2012; Maier et al., 2013; Hennige et al., 2015), though at a reduced rate (Maier et al., 2009; Lunden et al., 2014a). The ability to maintain calcification under low$\mathrm{pH}$ conditions has been explained by the capacity of cold-water corals to upregulate the $\mathrm{pH}$ of their internal calcifying fluid by up to 0.8 units (McCulloch et al., 2012; Wall et al., 2015).

The rapid pace of ongoing and projected ocean acidification is expected to outpace the natural capacity of marine species to survive through acclimatization or adaptation (Hoegh-Guldberg, 2014); this may prove especially true for cold-water corals which are generally long-lived, slow growing, and have a low fecundity. However, a growing body of literature supports the concept that acclimation or genetic adaptations may confer resilience to reduced pH conditions (e.g., Langer et al., 2009; Parker et al., 2011; Pistevos et al., 2011; Sunday et al., 2011; Pančić et al., 2015; Vargas et al., 2017). The evolution of adaptive capacities within a population may occur from novel mutations, but will likely depend heavily on the standing variation within the gene pool. Therefore, identifying existing variation in the response of single species to acidified seawater is a critical first step toward assessing their adaptive potential to future ocean acidification. Standing variation to acidification has been investigated in a number of marine organisms, including bryozoans (Pistevos et al., 2011), oysters (Parker et al., 2012), coccolithophores (Langer et al., 2009; Lohbeck et al., 2012), and sea urchins (Kelly et al., 2013). Notably for cold-water corals, Lunden et al. (2014a) found that Lophelia pertusa individuals from the Gulf of Mexico exhibited a highly variable calcification response to reduced $\mathrm{pH}$ conditions, suggesting that certain acidification-resistant genotypes may provide such an adaptive capacity.

In the present study, we performed both a short-term (2week) and long-term (6-month) assessment of the physiological performance of $L$. pertusa collected in the Gulf of Mexico after exposure to different levels of reduced $\mathrm{pH}$. In order to assess the differential response to altered carbonate chemistry at a genotype level, six different genotypes were included in the long-term experiment, and four of these six were also used in the shortterm experiment. We hypothesized that overall, decreased $\mathrm{pH}$ would elicit a negative response in the physiological performance of L. pertusa, but further hypothesized that some genotypes may be more resilient to the effects of ocean acidification. If upheld, this would imply a capacity for an evolutionary response to ocean acidification and an increased probability of persistence for scleractinian corals as they face future global climate and ocean change.

\section{MATERIALS AND METHODS}

\section{Study Species and Sample Collection}

Lophelia pertusa is a scleractinian cold-water coral that is found throughout the world's oceans, typically between 200 and $1,000 \mathrm{~m}$ (Rogers, 1999), although it occurs as shallow as $40 \mathrm{~m}$ in Norwegian fjords due to the upwelling of deep, cold water (Strømgren, 1971). In the Gulf of Mexico, L. pertusa is most commonly observed between depths of 300 and $600 \mathrm{~m}$, where it creates habitat that greatly increases local diversity (Cordes et al., 2008). Globally, its distribution is best explained by water temperature (Davies and Guinotte, 2011), while in the Gulf of Mexico, its distribution can best be predicted by depth, local topography, and the availability of hard substrata (Georgian et al., 2014).

L. pertusa were collected in the Gulf of Mexico in April and May 2014 on the R/V Atlantis using the DSV Alvin (Woods Hole Oceanographic Institution). All corals were collected at similar depths, temperature and carbonate chemistry conditions (Table 1) from the Viosca Knoll 826 (VK826) site (Cordes et al., 2008), named for the oil lease block governed by the 
TABLE 1 | Collection sites for each of the different genotypes used in the present study with its respective in situ carbonate chemistry conditions.

\begin{tabular}{|c|c|c|c|c|c|c|}
\hline & G1 & G2 & G3 & G4 & G5 & G6 \\
\hline Lat & 29.1727 & 29.1727 & 29.161 & 29.1729 & 29.173 & 29.1561 \\
\hline Long & -88.0189 & -88.0187 & -88.0157 & -88.019 & -88.0186 & -88.015 \\
\hline Depth (m) & 490 & 492 & 451 & 489 & 494 & 489 \\
\hline Temp $\left({ }^{\circ} \mathrm{C}\right)$ & 9.88 & 9.78 & 9.66 & 9.78 & 10.01 & 9.58 \\
\hline $\mathrm{pH}_{\mathrm{T}}$ & 7.84 & 7.87 & 7.87 & 7.86 & 7.88 & 7.86 \\
\hline Sal & 34.44 & 34.39 & 34.34 & 34.37 & 34.38 & 34.35 \\
\hline $\mathrm{TA}\left(\mu \mathrm{mol} \mathrm{kg}{ }^{-1}\right)$ & 2317 & 2317 & 2324 & 2316 & 2315 & 2318 \\
\hline $\mathrm{pCO}_{2}$ ( $\mu$ atm) & 641 & 602 & 604 & 611 & 576 & 611 \\
\hline $\mathrm{HCO}_{3}^{-}\left(\mu \mathrm{mol} \mathrm{kg}{ }^{-1}\right)$ & 2090 & 2079 & 2086 & 2081 & 2066 & 2084 \\
\hline $\mathrm{CO}_{3}^{2-}$ & 91 & 95 & 95 & 94 & 99 & 93 \\
\hline$\Omega_{\mathrm{ar}}$ & 1.27 & 1.32 & 1.33 & 1.31 & 1.38 & 1.30 \\
\hline
\end{tabular}

U.S. Bureau of Ocean Energy Management (BOEM). Each collection was carefully placed in a separate temperatureinsulated compartment on the submersible, and kept separate throughout the relocation and experiments. All live corals were kept in natural seawater and transported in insulated containers from Gulfport, Mississippi to Temple University, Philadelphia, Pennsylvania.

At the time of arrival, all corals were kept in a $550 \mathrm{~L}$ recirculating aquarium system with artificial seawater (ASW) prepared using Instant Ocean ${ }^{\circledR}$ (aquarium sea-salt mixture) and maintained at a temperature of $\sim 8^{\circ} \mathrm{C}$, salinity $35 \mathrm{ppt}$, and total alkalinity (TA) $\sim 2,300 \mu \mathrm{mol} \mathrm{kg}{ }^{-1}$ (for full description of the system see Lunden et al., 2014b). The corals were fed $20 \mathrm{~mL}$ of artificial MarineSnow ${ }^{\circledR}$ (Two Little Fishies) 3 days a week, as per comparable experimental procedures (Lunden et al., 2014a,b; Hennige et al., 2015; Georgian et al., 2016b). Corals were allowed to acclimate to laboratory aquaria conditions for a period of approximately 3 months prior to the start of experiments.

Paired water samples were collected directly above $(<2 \mathrm{~m})$ each of the six coral collection sites using vehicle-mounted Niskin bottles. Samples were measured for $\mathrm{pH}$ on the total scale $\left(\mathrm{pH}_{\mathrm{T}}\right)$ using an Orion 5 Star $\mathrm{pH}$ meter and glass electrode (ROSS Ultra pH/ATC Triode 8107BNUMD). Total alkalinity was measured by acid-titration on an autotitrator (Mettler-Toledo DL15, $0.1 \mathrm{~mol} \mathrm{~L}^{-1} \mathrm{HCl}$ ), with accuracy checked by measuring certified reference material (Dickson Lab, batches 138 and 141; Dickson et al., 2007). CO2Calc software (Robbins et al., 2010) was used to calculate $\mathrm{pCO}_{2}, \mathrm{HCO}_{3}^{-}, \mathrm{CO}_{3}^{2-}$, and $\Omega$ aragonite $\left(\Omega_{\mathrm{ar}}\right)$ using $\mathrm{pH}$ and total alkalinity as input variables with the dissociation constants for boric acid and $\mathrm{K} 1$ and $\mathrm{K} 2$ from Mehrbach et al. (1973) refit by Dickson and Millero (1987), $\mathrm{KHSO}_{4}$ from Dickson (1990), total boron from Lee et al. (2000), and $\mathrm{pH}$ on the total scale $\left(\mathrm{pH}_{\mathrm{T}}\right)$. In situ salinity, pressure, and temperature were measured using a vehicle-mounted CTD (Seabird SBE 49). For the full methodology of water sampling and analysis, see Georgian et al. (2016a).

\section{Determination of Coral Genotypes}

Corals were collected from six discontinuous reef patches within VK826 to increase the probability that different genotypes were sampled. Previous work indicates relatively low levels of clonality among distinct coral colonies at this site as compared to L. pertusa populations in the North Atlantic (Waller and Tyler, 2005; Lunden et al., 2014a). To ensure that distinct genotypes were used in our experiments, each coral fragment was genotyped according to methods used previously in a similar study of L. pertusa (Lunden et al., 2014a). Briefly, coral genotypes were determined using $10 \mathrm{~L}$. pertusa microsatellite loci (Morrison et al., 2008; Molecular Ecology Resources database entry 51059) from total DNA extracted from coral polyps. Of the six collections used in the live coral experiments, all of the microsatellite loci amplified, except for one collection in which only 6 of the 10 amplified. In all pairwise comparisons, the highest number of shared microsatellite genotypes was 2, the average was 0.8 , and in 7 of the 15 pairwise comparisons, there were no single-locus genotypes shared between the two individuals. These results indicate that each of the samples represents a distinct genotype.

\section{Manipulation of Seawater Chemistry}

Because Instant Ocean ${ }^{\circledR}$ at salinity 35 yields seawater with a total alkalinity of $\sim 3,600 \mu \mathrm{mol} \mathrm{kg} \mathrm{kg}^{-1}, 12.1 \mathrm{~N} \mathrm{HCl}$ was added to previously prepared artificial seawater (ASW) in order to reduce the total alkalinity to $\sim 2,300 \mu \mathrm{mol} \mathrm{kg}{ }^{-1}$ before adjusting the $\mathrm{pH}$ (Lunden et al., 2014b). The manipulation of the $\mathrm{pH}$ was accomplished by bubbling pure $\mathrm{CO}_{2}$ gas into the different treatment tanks using an automated $\mathrm{CO}_{2}$ injection system (American Marine Inc, PINPOINT $\mathrm{pH}$ Monitor). To reduce $\mathrm{pH}$, pure $\mathrm{CO}_{2}$ was mixed into a reaction chamber that dissolved the $\mathrm{CO}_{2}$ into seawater before being delivered into the respective tanks. If pH levels fell below the desired threshold, ambient air was automatically bubbled into the tank. The $\mathrm{pH}$ meters underwent a two-point Tris- $\mathrm{HCl}$ and $\mathrm{AMP}-\mathrm{HCl}$ calibration weekly (Dickson et al., 2007). In both experiments the $\mathrm{pH}_{\mathrm{T}}$ of the experimental tanks was gradually brought down to the desired treatment conditions at a rate of $\sim 0.1 \mathrm{pH}$ units day ${ }^{-1}$. Total alkalinity (TA) was measured twice a week as described above. Total alkalinity and $\mathrm{pH}_{\mathrm{T}}$ were used to calculate $\mathrm{pCO}_{2}, \mathrm{HCO}_{3}^{-}$, $\mathrm{CO}_{3}^{2-}$, and $\Omega_{\text {ar }}$ in CO2Calc software (Robbins et al., 2010) as described above. Salinity was measured daily using a handheld refractometer, and temperature was recorded every 5 min using a temperature logger (Onset HOBO Pendant ${ }^{\circledR}$ ). A $10 \%$ water 
change was performed weekly for the long-term experiment, and twice weekly for the short-term experiment.

\section{Short-Term Experiment}

The short-term experiment began in August 2014. Three $\mathrm{pH}_{T}$ treatments were selected: 7.90, which approximates the average in situ $\mathrm{pH}_{\mathrm{T}}$ at the VK826 collection site (Lunden et al., 2013); 7.75 , which results in seawater near the aragonite equilibrium point $\left(\Omega_{\mathrm{ar}}=1\right)$; and 7.6, which generates undersaturated seawater with respect to aragonite $\left(\Omega_{\mathrm{ar}}<1\right)$. Each treatment contained 12 fragments from four different genotypes (36 fragments in total). These treatments were established in three separate $50 \mathrm{~L}$ tanks housed in a cold room, which was maintained at $8^{\circ} \mathrm{C}$. Each of these fragments was weighed at the beginning and end of the 2-week $\mathrm{pH}$ exposure to determine net calcification rates.

\section{Long-Term Experiment}

In July 2014, the six collections were randomly split between two identical $550 \mathrm{~L}$ recirculating units (fully described in Lunden et al., 2014b). Two $\mathrm{pH}_{\mathrm{T}}$ treatments were selected: 7.90 as the control, and 7.60 as the treatment. The $\mathrm{pH}$ was gradually reduced in August 2014 to treatment conditions (control $=\mathrm{pH} 7.90$, acidified $=\mathrm{pH} 7.60)$. Fragments $(n=4)$ from each genotype $(n=6)$ of five to eight live polyps were set-aside in each tank for buoyant weighing every 2 weeks ( 48 fragments in total).

\section{Net Calcification}

The buoyant weight (BW) technique (Jokiel et al., 1978; Davies, 1989) was used to measure net calcification using a Denver Instruments SI-64 closed analytical balance (Precision of 0.1 $\mathrm{mg}$ ). All fragments from each treatment were weighed before the gradual $\mathrm{pH}$ decline, when the $\mathrm{pH}$ reached the desired treatment level, after 14 days, and in the long-term experiment, subsequently every 2 weeks for a 6 -month time period. The balance was closed within a plexiglass chamber to prevent any outside disturbance from affecting the weight. Each fragment was removed from its treatment tank and transported to the balance in a $4 \mathrm{~L}$ beaker without exposure to air. Fragments were gently attached to a monofilament fishing line, and suspended within the water from the bottom of the balance. After $10 \mathrm{~s}$ of stabilization, the weight was recorded. Each of the fragments in both the short- and long-term experiments was weighed in triplicate during each buoyant weight trial to minimize error.

Salinity and temperature of the water at time of weighing was recorded, and used to calculate the density of the water and to ensure that the treatment conditions were maintained throughout the weighing process. The dry weight of each fragment $\left(\mathrm{W}_{\mathrm{a}}\right)$ was calculated using the measured buoyant weight $\left(\mathrm{W}_{\mathrm{w}}\right)$, the density of the seawater during measurement $\left(D_{\mathrm{W}}\right)$, and the coral skeletal density $\left(\mathrm{SD}, 2.82 \mathrm{~g} \mathrm{~cm}^{-3}\right.$ ) (Lunden et al., 2013).

$$
W_{a}=\frac{W_{w}}{1-\frac{D_{w}}{S D}}
$$

Net calcification of $L$. pertusa was calculated as the change in weight over each 2 -week interval, expressed as $\%$ net calcification $\mathrm{d}^{-1}$. The average weight of the fragments at the start of the experiment was $15.81 \pm 7.39 \mathrm{~g}$. For the long-term experiment, net calcification rates were averaged monthly to yield a total of six time points. Percent net calcification per day was calculated by the equation described in Lunden et al. (2014a):

$$
N_{t}=100 \times \frac{W_{w 2}-W_{w 1}}{W_{w 1}\left(T_{2}-T_{1}\right)}
$$

where $\mathrm{W}_{w 2}$ and $\mathrm{W}_{w 1}$ is the final and initial standardized buoyant weight respectively, and $T_{1}$ and $T_{2}$ equal time 1 and time 2 , respectively.

\section{Carbonic Anhydrase Activity}

At the beginning and end of the long-term experiment, coral fragments from each genotype were selected to assess the potential effects of ocean acidification on enzyme activity. Collected corals were frozen in liquid nitrogen and stored in $-80^{\circ} \mathrm{C}$ until analyses were performed. Frozen coral polyps (2-3 polyps) from each genotype were extracted on liquid nitrogen, ground with a mortar to disrupt membrane cells, and homogenized with $3.5 \mathrm{~mL}$ of sterilized artificial seawater (ASW). The homogenate was centrifuged at $4^{\circ} \mathrm{C}$ for $3 \mathrm{~min}$ at 1,500 g. $200 \mu \mathrm{L}$ was reserved for total protein quantification using bicinchoninic acid assay (Pierce ${ }^{\mathrm{TM}} \mathrm{BCA}$ assay kit), and $1.5 \mathrm{~mL}$ of the remaining homogenate was transferred into a $7 \mathrm{~mL}$ scintillation vial and diluted $1: 1$ with $25 \mathrm{mM}$ veronal buffer. The in-vitro assay for carbonic anhydrase was performed according the protocol described by Weis et al. (1989), and was measured by the decrease in $\mathrm{pH}$ resulting from the hydration of $\mathrm{CO}_{2}$ to $\mathrm{HCO}_{3}^{-}$and $\mathrm{H}^{+}$after the addition of substrate $\left(\mathrm{CO}_{2}\right.$-enriched distilled $\mathrm{H}_{2} \mathrm{O}, \mathrm{pH}=3.5,4^{\circ} \mathrm{C}$ ). For each assay, $1 \mathrm{~mL}$ of buffered homogenate was transferred to a scintillation vial equipped with a magnetic stir bar and further diluted 1:1 with the same veronal buffer. The homogenate was maintained at $\sim 3.5^{\circ} \mathrm{C}$ before running the assay. The mixture was constantly stirred, and $1 \mathrm{~mL}$ of substrate was added to the sample when the $\mathrm{pH}$ stabilized and temperature reached $13^{\circ} \mathrm{C}$. From this time, the drop in $\mathrm{pH}$ was recorded every $10 \mathrm{~s}$ for a total of $120 \mathrm{~s}$. As a negative control for CA activity, a subsample of the homogenate $(\sim 1.7 \mathrm{~mL})$ was boiled for $5 \mathrm{~min}$ to denature the enzyme and treated as above. Enzyme activity was calculated as the difference of the decrease in $\mathrm{pH}$ between the sample with the active enzyme and the control with the denatured enzyme, and is given as enzyme units (EU) standardized to total protein content.

\section{Data Analysis}

For the short-term experiment, a two-way ANOVA was used with net calcification (change in mass as $\% \mathrm{~d}^{-1}$ ) as the dependent variable, $\mathrm{pH}$ as a fixed factor (three levels: $\mathrm{pH}=7.9,7.75,7.6$ ) and genotype as a random effect (6 levels). Multiple pair-wise comparisons were then applied to investigate the differential response to $\mathrm{pH}$ at the genotype level, using fragments within genotype $(n=12)$ as replicates. When considered together, the net calcification rate data were not normally distributed, and there were no simple transformations that resulted in a normal distribution. However, when considered separately, the data within each $\mathrm{pH}$ level were normally distributed. Furthermore, ANOVA is known to be very robust with respect to violations 
of this assumption (Schmider et al., 2010), and therefore we proceeded with the analysis as planned.

In the long-term experiments, a three-way factorial ANOVA was performed with growth $\left(\% \mathrm{~d}^{-1}\right)$ as the dependent variable, $\mathrm{pH}$ and time as fixed factors and genotype as a random effect, using each individual fragment as a replicate (Quinn and Keough, 2002). Tukey's HSD test was used to test for pairwise differences in the response of each genotype to the different $\mathrm{pH}$ treatments, where fragments within genotypes $(n=24)$ were used as replicates. Additionally, to investigate potential differences in the amount of time that a given genotype could maintain positive calcification in undersaturated conditions, survival curves were generated using Kaplan-Meier "time to event" analysis using a Mantel-Cox log rank test followed by a post-hoc Wilcoxon exact test to determine if significant differences were found (Kaplan and Maier, 1958). In this case, the "event" in question was the change from positive to negative calcification rate, and the time when negative calcification was first observed in each of the fragments of a given genotype within a treatment was used as the data in the analysis.

Differences in enzyme activity of $L$. pertusa at the end of the long-term experiment were assessed with a two-way ANOVA with $\mathrm{pH}$ (two levels) and time (initial and final time) as fixed factors. If significant differences were found, genotype was further analyzed by multiple pair-wise comparison. All analyses were applied to the mean standardized values of enzyme activity among replicate fragments of each genotype. For all the analyses, results were considered significantly different with $p<0.05$. All data are presented as average \pm standard deviation unless otherwise indicated.

\section{RESULTS}

\section{Aquaria Conditions}

Mean values of temperature, salinity and all carbonate chemistry parameters for the different treatments in both short and longterm experimental aquaria were relatively stable during the course of the two experiments. All parameters remained within a very narrow range around the target values of $8^{\circ} \mathrm{C}, 35 \mathrm{ppt}$, and $\mathrm{pH}$ values of 7.9, 7.75, and 7.6 (Table 2). These parameters, along with a total alkalinity near 2,300 resulted in $\Omega_{\text {ar }}$ values of approximately $1.5,1$, and 0.8 in the three treatment levels.

\section{Short-Term Experiment Net Calcification Rates}

Corals within the control $(\mathrm{pH}=7.9)$ and the slightly acidified treatments $(\mathrm{pH}=7.75)$ displayed the highest net calcification rate averaging $0.004 \pm 0.011$ and $0.006 \pm 0.003 \% \mathrm{~d}^{-1}$ respectively (Table 3). In the lowest $\mathrm{pH}$ treatment, skeletal dissolution was

TABLE 3 | Short- and long-term net calcification rates measured with the buoyant weight technique.

\begin{tabular}{|c|c|c|c|}
\hline Study & Duration & $\begin{array}{c}\text { Treatment } \\
\left(\mathrm{pH}_{\mathrm{T}}\right)\end{array}$ & $\begin{array}{c}\% \text { Calcification } \\
d^{-1} \pm \text { SD }\end{array}$ \\
\hline \multirow[t]{5}{*}{ Present Study } & 6 months & 7.60 & $-0.008 \pm 0.004$ \\
\hline & & 7.90 & $+0.006 \pm 0.006$ \\
\hline & 14 days & 7.60 & $-0.033 \pm 0.032$ \\
\hline & & 7.75 & $+0.006 \pm 0.003$ \\
\hline & & 7.90 & $+0.004 \pm 0.011$ \\
\hline \multirow[t]{3}{*}{ Georgian et al., 2016b } & 14 days & 7.60 & $-0.009 \pm 0.003$ \\
\hline & & 7.75 & $+0.018 \pm 0.010$ \\
\hline & & 7.90 & $+0.036 \pm 0.010$ \\
\hline \multirow[t]{3}{*}{ Lunden et al., 2014a } & 15 days & 7.60 & $-0.007 \pm 0.002$ \\
\hline & & 7.75 & $-0.003 \pm 0.003$ \\
\hline & & 7.90 & $+0.025 \pm 0.006$ \\
\hline \multirow[t]{7}{*}{ Form and Riebesell, 2012} & 8 days & 7.77 & $+0.001 \pm 0.003$ \\
\hline & & 7.83 & $+0.0007 \pm 0.003$ \\
\hline & & 7.96 & $+0.002 \pm 0.003$ \\
\hline & & 8.03 & $+0.007 \pm 0.003$ \\
\hline & 6 months & 7.76 & $+0.019 \pm 0.003$ \\
\hline & & 7.83 & $+0.011 \pm 0.006$ \\
\hline & & 7.94 & $+0.009 \pm 0.003$ \\
\hline
\end{tabular}

Rates were calculated as the difference between initial weight and weight at the time of measurement for each fragment, and are presented as \% increase in calcification day ${ }^{-1}$. For comparative purposes, the calcification rates from the studies by Lunden et al. (2014a) and Georgian et al. (2016b) conducted with Lophelia pertusa from the Gulf and Mexico, and Form and Riebesell (2012) conducted with L. pertusa from the North Atlantic.

TABLE 2 | Summary of seawater chemistry parameters from each of the treatments for both long-and short-term experiments.

\begin{tabular}{|c|c|c|c|c|c|}
\hline & \multicolumn{2}{|c|}{ Long-term } & \multicolumn{3}{|c|}{ Short-term } \\
\hline $\mathrm{pH}_{\mathrm{T}}$ & $7.91 \pm 0.04$ & $7.65 \pm 0.07$ & $7.91 \pm 0.07$ & $7.74 \pm 0.02$ & $7.62 \pm 0.03$ \\
\hline Salinity & $35 \pm 0$ & $35.5 \pm 0.7$ & $36 \pm 1$ & $35.66 \pm 1.15$ & $36 \pm 1$ \\
\hline $\mathrm{TA}\left(\mu \mathrm{mol} \mathrm{kg}{ }^{-1}\right)$ & $2292 \pm 64$ & $2434 \pm 45$ & $2266 \pm 52$ & $2250 \pm 55$ & $2305 \pm 20$ \\
\hline $\mathrm{HCO}_{3}^{-}(\mu \mathrm{mol} \mathrm{kg}-1)$ & $2052 \pm 65$ & $2314 \pm 95$ & $2017 \pm 47$ & $2083 \pm 47$ & $2171 \pm 9$ \\
\hline $\mathrm{CO}_{2}\left(\mu \mathrm{mol} \mathrm{kg}{ }^{-1}\right)$ & $26 \pm 3$ & $54 \pm 10$ & $25 \pm 1$ & $39 \pm 1$ & $51 \pm 6$ \\
\hline $\mathrm{CO}_{3}^{2-}\left(\mu \mathrm{mol} \mathrm{kg}{ }^{-1}\right)$ & $95 \pm 9$ & $59 \pm 9$ & $99 \pm 2$ & $66 \pm 4$ & $53 \pm 5$ \\
\hline$\Omega_{\mathrm{ar}}$ & $1.43 \pm 0.14$ & $0.90 \pm 0.14$ & $1.49 \pm 0.04$ & $0.99 \pm 0.06$ & $0.81 \pm 0.06$ \\
\hline
\end{tabular}

Maximum and minimum values are not provided as there are no substantial deviations to report. Values are given in mean $\pm S D$. 
observed at a rate of $-0.033 \pm 0.032 \%$ day $^{-1}$ (Table 3, Figure 1), although there was no significant effect due to $\mathrm{pH}$ [ANOVA $F_{(2,24)}=1.03, P=0.412$ ] due to the high variance observed in net calcification rate measurements. There was also no significant difference in the overall net calcification rate of the different genotypes when averaged among treatments [ANOVA $F_{(3,24)}=$ $1.119, P=0.413]$. However, there was a significant interaction term between $\mathrm{pH}$ and genotype [ANOVA $F_{(6,24)}=2.575, P=$ 0.045] (Table 4), indicating that different genotypes had different responses to the three $\mathrm{pH}$ treatments. If the two extreme values from $\mathrm{G} 1$ are dropped from this analysis, then the significance level of the interaction is $P=0.052$, indicating that the hypothesis that different genotypes responded differently to changes in $\mathrm{pH}$ was still moderately supported. On average, genotype 1 (G1) and G3 experienced net dissolution (negative calcification) in the highly acidified treatment $(\mathrm{pH}=7.6)$ with $-0.144 \pm 0.0156$ and $-0.0008 \pm 0.001 \%$ net calcification $\mathrm{d}^{-1}$ respectively, whereas G4 experienced significant positive net calcification at a rate of $0.013 \pm 0.001 \% \mathrm{~d}^{-1}$ in the same treatment (Figure 1). In particular, within the highly acidified treatment all three of the

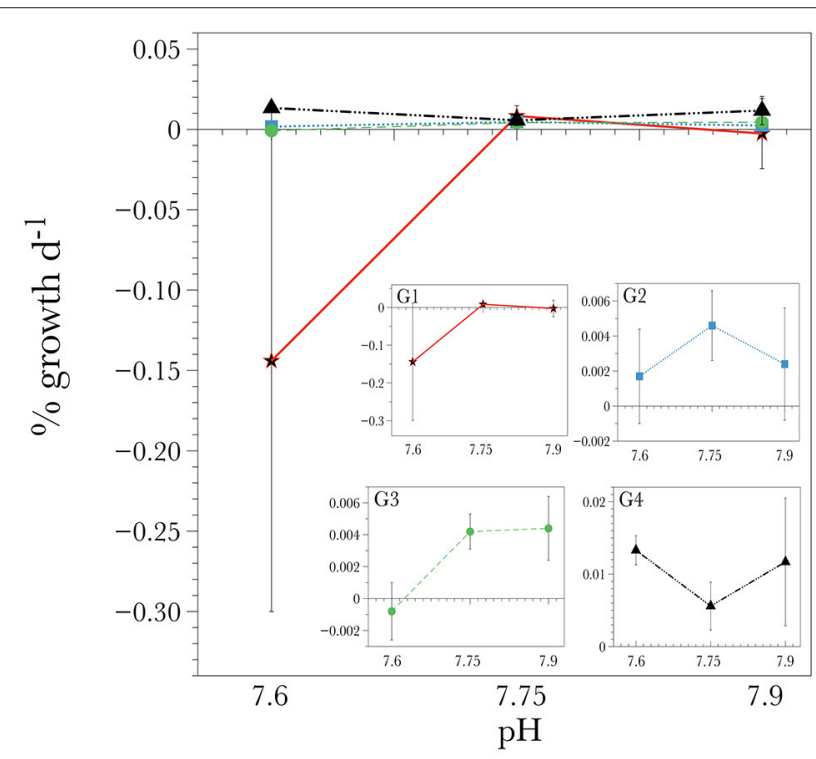

FIGURE 1 | Short-term calcification response of individual genotypes of $L$. pertusa corals in the different ocean acidification conditions. G1 through $\mathrm{G} 4$ refers to each genotype. Values are given as mean \pm S.D

TABLE 4 | Short-term experiment ANOVA.

\begin{tabular}{lccccc}
\hline Source of variation & $\boldsymbol{d} \boldsymbol{f}$ & SS & MS & $\boldsymbol{F}$ & $\boldsymbol{P}$ \\
\hline $\mathrm{pH}$ & 2 & 0.011 & 0.006 & 1.033 & 0.412 \\
Gen & 3 & 0.018 & 0.006 & 1.119 & 0.413 \\
$\mathrm{pH}^{*}$ Gen & 6 & 0.032 & 0.005 & 2.575 & 0.045 \\
Error & 24 & 0.050 & 0.002 & & \\
\hline
\end{tabular}

Calcification of $L$. pertusa was the dependent variable, $\mathrm{pH}$ was treated as a fixed factor and genotype (Gen) as a random effect. Degree of freedom (df), type III sum squares (SS), mean square (MS), F-ratio (F), and p-value $(P)$. Significant differences when $p<0.05$. fragments from G4 had the highest positive calcification of any of the individual nubbins. However, pairwise post-hoc comparisons of net calcification rates indicated that the only genotype with a significantly different net calcification rate over the treatments was $\mathrm{G} 1$ in the low $\mathrm{pH}$ treatment (Tukey HSD, $P<0.034$ for all 11 pairwise comparisons). This difference was mainly driven by the highly negative net calcification rate measured in two of the three fragments in undersaturated conditions (Figure 1). The third individual had a net calcification rate of $+0.003 \% \mathrm{~d}^{-1}$, which is within the range of the other fragments at higher $\mathrm{pH}$.

\section{Long-Term Experiment Net Calcification Rates}

The average net calcification rate in the control treatment $(\mathrm{pH}$ $=7.90$ ) was $0.0057 \pm 0.006 \%$ net calcification $\mathrm{d}^{-1}$, while in the low $\mathrm{pH}(\mathrm{pH}=7.60)$ treatment it was $-0.0078 \pm 0.0043 \%$ net calcification $\mathrm{d}^{-1}$. Although variability in the response of different individuals was evident, the overall trend of positive calcification at $\Omega_{\mathrm{ar}}>1$ and dissolution at $\Omega_{\mathrm{ar}}<1$ was still observed (Table 3, Figures 2A,B). All genotypes in the $\mathrm{pH} 7.6$ treatment started to exhibit negative calcification rates as the experiment progressed, with net dissolution in $100 \%$ of the fragments by the end of the experiment (Figure 3). The three-way ANOVA indicated significant differences in the main effects of overall net calcification rate in the two treatments $\left[F_{(1,199)}=49.09, P=\right.$ $0.001]$, and average net calcification rate over time $\left[F_{(5,199)}=\right.$ 8.44, $P<0.001]$, but no significant difference in overall net calcification rate among genotypes $\left[F_{(5,199)}=1.01, P=0.495\right]$. In addition, the interaction terms between $\mathrm{pH}$ treatment and time $\left[F_{(5,199)}=4.21, P=0.006\right]$ as well as treatment and genotype were significant $\left[F_{(5,199)}=2.73, P=0.04\right]$ (Table 5).

The treatment $\mathrm{x}$ genotype interaction is more complex and was explored using post-hoc pairwise comparisons. In this analysis, every pairwise comparison between the overall average net calcification rate of a given genotype in the $\mathrm{pH} 7.9$ treatment and the same genotype's average net calcification rate at $\mathrm{pH}$ 7.6 was significant (Tukey HSD, $P<0.021$ for 5 of the 6 comparisons), except for G5, which did not show a significant difference between treatments (Tukey HSD, $P=0.828$ ). However, the net calcification rate of G5 in the low $\mathrm{pH}$ treatment was also not significantly different from any of the other genotypes in the low $\mathrm{pH}$ treatment (Tukey HSD, $P>0.645$ for all 5 comparisons). The lack of significance in these tests can primarily be attributed to the high intra-genotype variance in net calcification rate, as one of the G5 fragments exhibited highly negative calcification at two of the time points in the low $\mathrm{pH}$ treatment (time 2 and time 4, Figure 3).

To further examine the potential differences in the response of genotypes to low $\mathrm{pH}$ and carbonate ion availability, a time-toevent survival analysis was used to determine which genotypes were capable of maintaining positive calcification the longest (Figure 4). Notably, out of the six genotypes being used in the experiment, two (G3 and G4) maintained positive net calcification $\left(0.0115\right.$ and $0.00964 \% \mathrm{~g} \mathrm{~d}^{-1}$ respectively for the first 90 days) in the acidified ( $\mathrm{pH} \mathrm{7.6)} \mathrm{treatment,} \mathrm{significantly}$ longer than the other genotypes (Kaplan-Meier survival analysis 

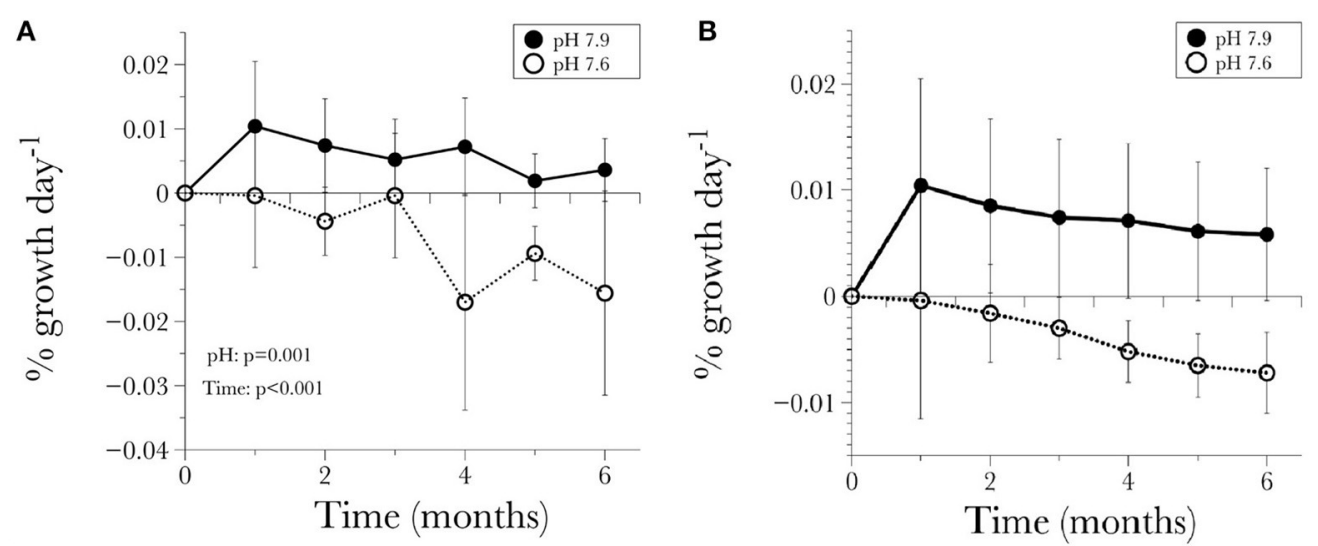

FIGURE 2 | (A) Long-term time-series of the calcification response of L. pertusa standardized by the initial weight for each time point, (B) calcification response standardized by initial weight $t_{0}$ at the beginning of the experiment. Values are given as mean \pm S.D.

Mantel-Cox $X^{2}=19.148, p<0.01$; post-hoc Wilcoxon exact test $p<0.05$; Figure 4, Table 6).

\section{Carbonic Anhydrase Activity}

No significant differences were observed in the average carbonic anhydrase activity for corals grown in the $\mathrm{pH} 7.9$ vs. $\mathrm{pH} 7.6$ $\left[F_{(1,19)}=0.32, P=0.59\right]$. The average activity at the initial time point was $0.010 \pm 0.003 \mathrm{EU}$ for corals in the $\mathrm{pH} 7.9$ and 0.006 $\pm 0.003 \mathrm{EU}$ for corals in $\mathrm{pH} 7.6$ (Figure 5). After 6 months the average activity was similar for control conditions ( $\mathrm{pH} 7.9)$ with an average $0.010 \pm 0.006 \mathrm{EU}$, however, it increased in the low $\mathrm{pH}$ treatment (7.6) with an average $0.013 \pm 0.012 \mathrm{EU}$ (Figure 5), although this was not significant due to the high variability in the enzyme activity $\left[F_{(1,19)}=0.32, P=0.32\right]$. The maximum average activity was measured at the low $\mathrm{pH}$ final time point for G2 $0.031 \mathrm{EU}$, followed by G5 at the control conditions with a value of 0.020 EU (Figure 5).

\section{DISCUSSION}

The present study examined the potential effects of short- (2 weeks) and long-term (6 months) low- $\mathrm{pH}$ exposure on the physiological response of cold-water coral L. pertusa from the Gulf of Mexico. This vital ecosystem is particularly vulnerable to ongoing climate and ocean change as many of these habitats are rapidly approaching undersaturated carbonate conditions (Lunden et al., 2013; Georgian et al., 2016a), and L. pertusa appears to be living near the edge of its viable niche in the Gulf of Mexico (Lunden et al., 2014a; Georgian et al., 2016b). As cold-water coral habitats are becoming increasingly acidified, the calcification of new skeleton is expected to slow and existing skeletal structures may start dissolving (Andersson et al., 2008). This would result in a loss of ecologically significant primary habitat and regional habitat heterogeneity along continental slopes worldwide (Rogers, 1999; Roberts et al., 2006). In this study, we found an overall trend of decreased calcification rate under exposure to undersaturated conditions, but this response took between 2 weeks and 3 months to manifest in the genotypes examined here. In addition, there was a relatively high degree of variance in the response of individual genotypes across experiments, particularly in the short-term experiment. These findings provide evidence that the existing intra-specific variability in Gulf of Mexico L. pertusa populations may confer a higher degree of resistance to ocean acidification than was previously expected.

\section{Short-Term Calcification Response}

Our results did not show a statistically significant response in the short-term (2-week) exposure to low $\mathrm{pH}$ in L. pertusa; however, this was primarily due to the extremely high variability in the response of different genotypes within the $\mathrm{pH} 7.6$ treatment. Short-term experiments of ocean acidification with Gulf of Mexico L. pertusa populations have found reductions in net calcification rate with the same $\mathrm{pH}$ treatments (Lunden et al., 2014a; Georgian et al., 2016b). Lunden et al. (2014a) found that short-term low $\mathrm{pH}$ exposure had an overall negative effect on calcification, although some coral fragments were able to maintain positive calcification rates even at undersaturated levels of aragonite. Moreover, Georgian et al. (2016b) found a 48\% decline in net calcification of L. pertusa grown at $\mathrm{pH} 7.75$, and the net dissolution of L. pertusa grown at $\mathrm{pH}$ of 7.6. In the low $\mathrm{pH}$ treatment $(\mathrm{pH}=7.6)$ in this study, average net dissolution was also observed. However, we observed extremely high variability among genotypes, but consistent responses within genotype. Genotype G4 maintained significantly positive calcification rates in all individuals during the short-term exposure to undersaturated conditions.

Other short-term experiments with cold-water corals including different populations of Lophelia pertusa from the North Atlantic and Mediterranean Sea have shown contrasting results. Despite these inconsistencies, there is evidence for declines in calcification as pH decreases (Maier et al., 2009; Form and Riebesell, 2012). For example, a study using the reef-building cold-water coral Madrepora occulata, found that calcification rates are 50\% slower than in pre-industrial times, and suggesting that ocean acidification has already impaired cold-water coral 


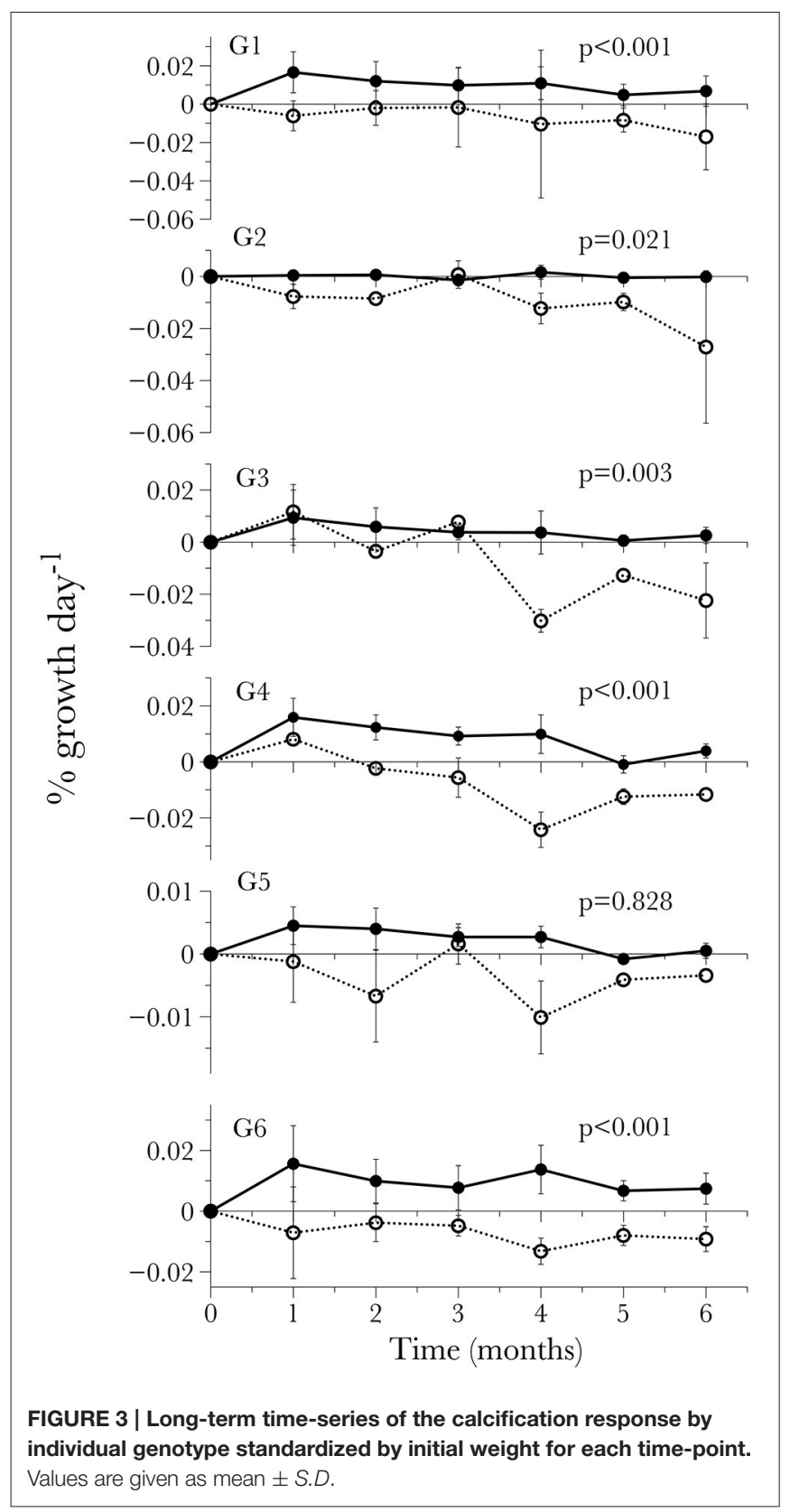

calcification (Maier et al., 2012). Moreover, Maier et al. (2009) found that lowering $\mathrm{pH}$ by 0.15 to 0.3 units (from an initial value of $\mathrm{pH}$ 8.1) according to future scenarios of ocean acidification resulted in a decrease in $L$. pertusa's gross calcification by 30 and $56 \%$ respectively.

In our study, coral fragments in the control treatment $(\mathrm{pH}=$ 7.9) and the slightly acidified treatment $(\mathrm{pH}=7.75)$ maintained similar calcification rates. The similar calcification rates between the control and the 7.75 treatment can likely be attributed to the fact that both treatments were still supersaturated with respect to aragonite $\left(\Omega_{\mathrm{ar}}\right)$, therefore positive calcification was still energetically favored and dissolution was not likely to occur. These results are similar to the in situ deep-water
TABLE 5 | Long-term experiment three-way factorial ANOVA with calcification as the dependent variable showing the effect of time, $\mathrm{pH}$ treatment, and genotype.

\begin{tabular}{lcccrc}
\hline Source of variation & $\boldsymbol{d f}$ & SS & MS & $\boldsymbol{F}$ & $\boldsymbol{P}$ \\
\hline Time & 5 & 0.004 & 0.001 & 8.443 & 0.000 \\
$\mathrm{pH}$ & 1 & 0.011 & 0.011 & 49.098 & 0.001 \\
Genotype & 5 & 0.001 & 0.000 & 1.006 & 0.495 \\
Time* $\mathrm{pH}$ & 5 & 0.002 & 0.000 & 4.212 & 0.006 \\
Time $^{*}$ Genotype & 25 & 0.002 & 0.000 & 1.153 & 0.365 \\
$\mathrm{pH}^{*}$ Genotype & 5 & 0.001 & 0.000 & 2.735 & 0.043 \\
Time* $\mathrm{pH}^{*}$ Genotype & 24 & 0.002 & 0.000 & 1.065 & 0.388 \\
Error & 199 & 0.016 & 0.000 & &
\end{tabular}

Time and $\mathrm{pH}$ were treated as fixed factors and genotype as random effect. Degree of freedom (df), type III sum squares (Sum sq), mean square (Mean sq), F-ratio (F), and $p$-value $(P)$. Significant differences when $p$-value $<0.05$.

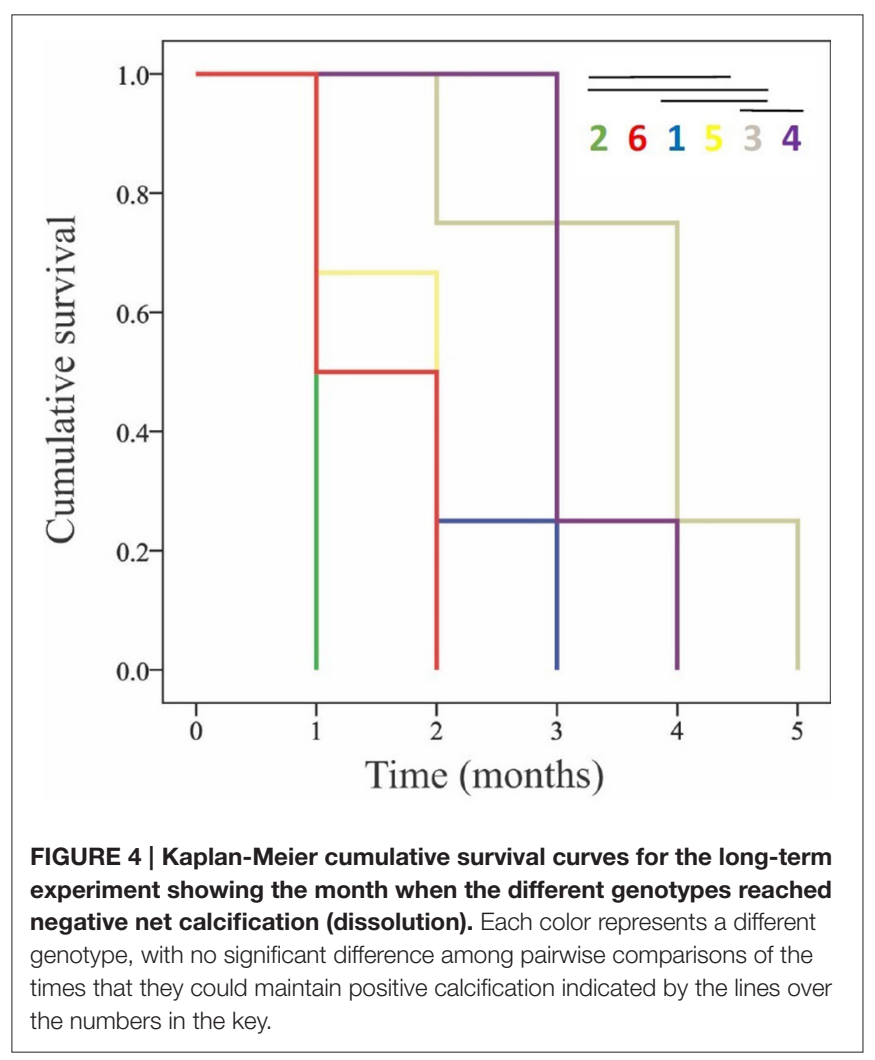

(McCulloch et al., 2012; Wall et al., 2015) and shallow-water (Cohen and McConnaughey, 2003; Venn et al., 2013; Holcomb et al., 2014) studies that have found corals growing in low $\mathrm{pH}$ conditions, presumably due to specialized cellular mechanisms for maintaining elevated $\mathrm{pH}$ and carbonate ion concentration within the calcifying fluid.

In the short-term experiment, two of the three replicate fragments from G1 displayed a very high net dissolution rate, while all of the replicates of G4 had positive net calcification within the low $\mathrm{pH}$ treatment. It should be noted that the overall net calcification rates reported here for the high $\mathrm{pH}$ treatments, designed to simulate ambient in situ conditions, were lower 
than those found in the previous studies of Gulf of Mexico L. pertusa populations, although within the range of these and other studies (Table 3). Since these studies were conducted in the same laboratory using the same methodology by many of the same scientists, it is possible that some of the coral fragments examined here were in a poorer condition at the time of collection than those collected in previous years, or that they included some genotypes that simply do not perform as well under ambient conditions.

The fact that genotype G4 was able to calcify under low $\mathrm{pH}$ and undersaturated conditions suggests that these corals may have started with larger energy reserve, such as carbohydrates, lipids, or proteins, allowing them to allocate additional energy to the calcification process, and as has been found in shallowwater calcifying corals that maintain calcification rates under environmental stress (Rodrigues and Grottoli, 2007; Schoepf et al., 2013). When comparing Gulf of Mexico and Norwegian L. pertusa populations, Georgian et al. (2016b) attributed the higher calcification rates of the Norwegian corals to higher food supply at the shallower Norwegian sites and an elevated

TABLE 6 | Post-hoc pair-wise comparisons for Kaplan-Meier analysis between different genotypes for low pH treatment in the long-term experiment.

\begin{tabular}{lllllll}
\hline & Gen 1 & Gen 2 & Gen 3 & Gen 4 & Gen 5 & Gen 6 \\
\hline Gen 1 & $-\cdot-$ & NS & NS & $* *$ & NS & NS \\
Gen 2 & NS & $-\cdot-$ & $* *$ & $* *$ & NS & NS \\
Gen 3 & NS & $* *$ & $-\cdot-$ & NS & NS & $* *$ \\
Gen 4 & $* *$ & $* *$ & NS & $-\cdot-$ & $* *$ & $* *$ \\
Gen 5 & NS & NS & NS & $* *$ & $-\cdot-$ & NS \\
Gen 6 & NS & NS & $* *$ & $* *$ & NS & $-\cdot-$
\end{tabular}

No significant (NS), significant differences when $\left.p<0.05{ }^{(\star *}\right)$. metabolic response of the corals. However, increased food supply did not confer an increased resilience to lower $\mathrm{pH}$ in Madrepora oculata from the Mediterranean Sea (Maier et al., 2016). It is also possible that certain genotypes are more resilient to low-pH stress via mechanisms not yet understood, but plausibly related to the up-regulation of the calcification pathway or certain stress genes and pathways (Carreiro-Silva et al., 2014) that warrant further investigation.

The finding of a variable response of $L$. pertusa genotypes to the undersaturated treatment reflects the disparate results from the literature. In the short-term experiment here, two of the genotypes exhibited net dissolution (G1 and G3), while one of the genotypes (G4) was capable of maintaining significant positive net calcification in undersaturated conditions $\left(\Omega_{\mathrm{ar}}=0.81\right.$, range 0.76-0.85). This is similar to previous experiments with $L$. pertusa from the Gulf of Mexico (Lunden et al., 2014a), where a few of the genotypes tested were capable of positive calcification in undersaturated conditions, although the former experiment was not designed to include genetic replicates. Maier et al. (2009) found that L. pertusa from two different populations in the North Atlantic were able to calcify in slightly undersaturated levels of aragonite $\left(\Omega_{\mathrm{ar}}=0.97\right)$ albeit at reduced calcification rates. However, the authors used ${ }^{45} \mathrm{Ca}$ to measure gross calcification over a 24-h period, which does not take into account possible dissolution effects, while the buoyant-weight technique used here integrates both biologically mediated calcification and chemical dissolution. Therefore, is plausible that all of our coral fragments in the highly acidified treatment $(\mathrm{pH}=7.6)$ were still able to calcify, but at slower rates that are insufficient to compensate for skeletal dissolution.

\section{Long-Term Calcification Response}

This is the first long-term experiment performed on L. pertusa from the Gulf of Mexico, although long-term experiments

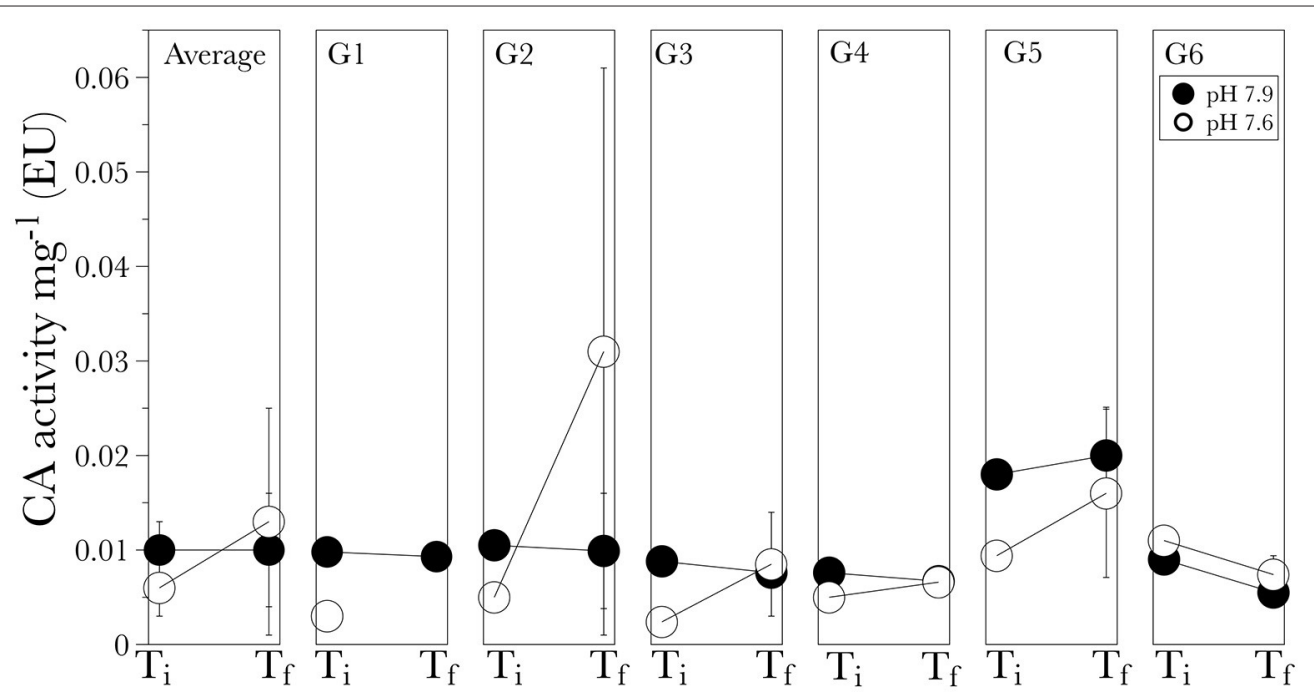

FIGURE 5 | Carbonic anhydrase activity for the long-term experiment shown for the average of all genotypes (general) and for individual genotypes (G1 through G6). $T_{i}$ is the initial time point and $T_{f}$ is the final time point after the six-month experiment. Values are given as mean \pm S.D. 
have been conducted using L. pertusa from the North Atlantic (Form and Riebesell, 2012; Hennige et al., 2015), and the Mediterranean sea (Maier et al., 2013; Movilla et al., 2014). Our results showed a significant effect of time and $\mathrm{pH}$, where corals in the control treatment ( $\mathrm{pH}$ 7.9) maintained positive net calcification, while, on average, corals in the acidified treatment $(\mathrm{pH}=7.6)$ experienced declining net calcification rate over time and net dissolution by the end of the 6-month period. On average, corals were not able to maintain calcification even after only 1 month in the low $\mathrm{pH}$ treatments, however there was a variable response among genotypes over time. Genotype 3 maintained positive net calcification for 2 months, and G4 displayed positive net calcification for approximately 3 months before net dissolution started to occur, longer than any of the other genotypes (Figure 4). This provides evidence for an adaptive capacity in this population of $L$. pertusa that would improve its probability of surviving predicted levels of ocean acidification.

These results contrast with what has been found so far in other long-term experiments where there has not been a significant negative response in calcification for L. pertusa (Form and Riebesell, 2012; Maier et al., 2013; Movilla et al., 2014; Hennige et al., 2015) and for other cold-water coral species (Carreiro-Silva et al., 2014; Rodolfo-Metalpa et al., 2015; Gori et al., 2016). However, the majority of the studies performed in cold-water corals to date have used $\mathrm{pH}$ levels that still yielded $\Omega_{\text {ar }}$ saturation states at or near 1 . Form and Riebesell (2012) found that in the long-term (six months), corals exposed to low $\mathrm{pH}$ conditions ( $\mathrm{pH}: 7.75 ; \Omega_{\mathrm{ar}}$ : 0.93 ) experienced no significant change in calcification compared to control conditions suggesting an acclimation potential. Maier et al. (2013) and Movilla et al. (2014) in different experiments with L. pertusa and $M$. oculata, did not find any significant difference in net calcification after 9 and 6 month experiments respectively, however, all of the treatments in those studies were saturated with respect to aragonite $\left(\Omega_{\mathrm{ar}}>1\right)$. Likewise, Carreiro-Silva et al. (2014) performed a long-term experiment (8 months) on the cold-water coral Desmophylum diantus subjected to two levels of $\mathrm{pH}$ that simulated ambient $(\mathrm{pH} 8)$ and acidified conditions $(\mathrm{pH}$ 7.7) and found no significant differences in average net calcification, however their experiment were never subjected to undersaturation for aragonite. In this study, none of the $L$. pertusa genotypes examined were capable of maintaining positive net calcification beyond 90 days in undersaturated conditions. Although we did not measure gross calcification in the present study, it is clear that dissolution is an important factor controlling overall calcification and net calcification rates in the natural environment, and measurements of gross calcification should be incorporated into future studies (Rodolfo-Metalpa et al., 2015).

The most recent direct comparison to the present study, because of the inclusion of a treatment with $\Omega_{\mathrm{ar}}<1$, measured net calcification in $L$. pertusa populations from the North Atlantic subjected to undersaturated conditions (Hennige et al., 2015). Although they did not find evidence for a significant response in net calcification rate, their data showed a negative trend with calcification rates approaching zero at undersaturated levels of aragonite. However, it is important to bear in mind that this maintenance of calcification under ocean acidification scenarios comes with a significant energetic cost. Norwegian populations of $L$. pertusa were found to be able to maintain calcification only by increasing their feeding and respiration rates, while the Gulf of Mexico populations did not exhibit this physiological response (Georgian et al., 2016b).

\section{Population and Genotypic Variability in Response to Ocean Acidification}

Environmental differences between the regions may account for some of the variability among experiments conducted in different regions, as relatively isolated $L$. pertusa populations (Morrison et al., 2011; Lunden et al., 2014a) may have acclimated or adapted to local $\mathrm{pH}$ and carbonate conditions. The corals used here were collected from 400 to $500 \mathrm{~m}$ at an ambient $\mathrm{pH}$ of approximately 7.9 (Table 1), as opposed to the North Atlantic and Norwegian corals that were collected from a depth of $70-150 \mathrm{~m}$ and a $\mathrm{pH}$ of approximately 8.0 to 8.1 (Maier et al., 2009; Form and Riebesell, 2012). Positive calcification rates were maintained in an experiment on Norwegian corals due to an increase in feeding rate and higher metabolic rate (Georgian et al., 2016b), and these mechanisms will remain effective as long as food supplies are sufficient. Model simulations indicate that $L$. pertusa reefs induce downwelling of organic-carbon rich waters, which would serve to ensure a consistent food supply (Soetaert et al., 2016), at least while surface productivity rates remain consistent. Even though overall net calcification is positive in lab experiments at low $\mathrm{pH}$ and undersaturation of aragonite, dissolution of coral fragments has been noted, particularly in areas that were not covered by tissue (Hennige et al., 2015). There was also a decrease in the breaking strength of new skeletal structure, changes in the crystallographic organization, as well as thinner corallites grown in high $\mathrm{CO}_{2}$ (Hennige et al., 2015). Furthermore, Gulf of Mexico L. pertusa populations (Georgian et al., 2016b) and Mediterranean M. oculata populations (Maier et al., 2016) do not appear to be able to increase feeding rate to compensate for the increased energetic cost of calcification at low saturation states. These changes have the capacity to alter the stability of reef frameworks in the future.

Standing genetic variation and local adaptation may play a role in species persistence in a changing ocean. Kelly et al. (2013) tested the responses of larval Strongylocentrotus purpuratus cultured under varying $\mathrm{pCO}_{2}$ conditions, and observed differences in larval length among individuals collected from two different populations characterized by different $\mathrm{CO}_{2}$ regimes. The authors found that urchins from naturally high$\mathrm{CO}_{2}$ environments were less sensitive to $\mathrm{OA}$, implying a capacity for adaptation to ocean acidification. In a related study using several populations of S. purpuratus, Pespeni et al. (2013) observed rapid selection of genes encoding proteins involved in calcification under acidification, demonstrating a potential for rapid evolution to occur in this species. Generally, in slowgrowing organisms with long-generation times such as coldwater corals, persistence in a changing ocean will likely hinge on the maintenance of genetic diversity and the success of resilient genotypes, the potential for individual acclimatization, or local 
adaptation among populations in the presence of both selection and gene flow (Palumbi and Sotka, 2006). While it is unknown if the observed resilience within certain genotypes to climate change stressors in the present study of L. pertusa is heritable, the general consistency in the response of different nubbins of the same genotype within and among different experiments provides evidence for the adaptive capacity of this species.

Identification of the variability of responses due to genetics may lead to future studies of the mechanisms underlying such variation. One mechanism responsible for this could be differential expression of calcification genes. A recent study using next-generation sequencing techniques observed significant effects of $\mathrm{OA}$ on gene expression in larvae and primary polyps of the scleractinian coral Acropora millepora (Moya et al., 2012). Notably, genes involved in $\mathrm{CaCO}_{3}$ deposition showed patterns of differential expression under $\mathrm{OA}$, including down-regulation of genes encoding proteins that support the skeletal organic matrix. It is unclear if this study employed true biological replicates, and different genotypes will likely have different thresholds for their transcriptomic response. An interesting question for future work would be to investigate the potential for different individuals or populations to balance these processes under acidification, as has been observed in natural coral populations responding to thermal stress (Barshis et al., 2013).

\section{Carbonic Anhydrase Activity and Calcification}

We did not detect any significant change in the overall activity for carbonic anhydrase in the long-term experiment. Lophelia pertusa maintained stable activity after a 6-month exposure, but exhibited higher variability in the low $\mathrm{pH}$ treatment. While our measured values (between 0.002 and 0.031 units of enzyme activity) are low compared to studies of zooxanthellate corals, it has been found that CA activity in zooxanthellate corals is 29 times higher than in azooxanthellate species (Weis et al., 1989). Reported values for CA activity in the azooxanthellate coral Tubastrea aurea were 0.08 units of enzyme activity Weis et al. (1989) reported similar values of 0.06 units for different species of azooxanthellates, which are close to the values obtained here.

In the low $\mathrm{pH}$ treatment, there was a slight increase in overall CA activity due to two genotypes that showed increased activity despite a decrease in net calcification. Calcification in scleractinian corals occurs in a biologically mediated environment (Allemand et al., 2011) and carbonic anhydrase actively participate in the calcification process (Tambutté et al., 2007; Moya et al., 2008; Bertucci et al., 2013). In symbiotic scleractinians, reductions in calcification are correlated with decreased enzyme activities (Goreau, 1959; Weis et al., 1989), where calcification is tightly linked with photosynthesis and CA acts as a $\mathrm{CO}_{2}$ supplier for the endosymbiont (Weis et al., 1989). However, metabolic $\mathrm{CO}_{2}$ is not the main source of DIC for calcification in deep-water corals (Adkins et al., 2003; Mueller et al., 2013). An increase in $\mathrm{CO}_{2}$ will cause an increase in DIC, specifically by producing $\mathrm{HCO}_{3}^{-}$and $\mathrm{H}^{+}$, which ultimately will alter the internal chemistry and lower the $\mathrm{pH}$ inside the cells (Allemand et al., 1998). It is plausible that the role of the isoform of $\alpha \mathrm{CA}$ found in corals (Bertucci et al., 2013), is to regulate the build-up of $\mathrm{H}^{+}$ions that result from the hydration of $\mathrm{CO}_{2}$ to $\mathrm{HCO}^{3-}$ in order to avoid internal acidosis. This has been suggested for the scleractinians Stylophora pistillata (Moya et al., 2008), and the cold water coral Desmophyllum dianthus (Carreiro-Silva et al., 2014), where an over-expression of the genes that encode for CA was found when high levels of $\mathrm{H}^{+}$were present in the internal compartments of the cells.

\section{CONCLUSIONS}

These data suggest that further ocean acidification will negatively impact L. pertusa reefs in the Gulf of Mexico, although transient exposures may not have a significant effect, and some genotypes might be more resilient than others. It has been previously stated that ecosystems in the Mediterranean Sea are likely to show the first signs of ocean acidification (Calvo et al., 2011), but our results coupled with previous work (Lunden et al., 2014a; Georgian et al., 2016b) suggest that the deep-water coral ecosystems of the Gulf of Mexico are also extremely vulnerable. Reductions in calcification rate and increased dissolution of standing dead skeleton would cause instability and degradation of the deep reef structures, which would lead to biodiversity loss and cascading effects throughout the larger Gulf of Mexico ecosystem. However, the finding that some genotypes are able to maintain calcification in undersaturated waters for between 2 weeks and 3 months may offer hope for the population as a whole. It is possible that these resistant genotypes will survive the onset of predicted levels of acidification and provide an avenue for adaptive resilience to future climate change. Future work would benefit from examining the genotypic response to acidification and other stressors, with a particular focus on the genetic and physiological mechanisms underlying the resilience of certain genotypes of cold-water corals.

\section{AUTHOR CONTRIBUTIONS}

MK conducted the experiments, performed data analysis, and wrote the manuscript. CG designed and conducted the experiments, performed data analysis, and edited the manuscript. SG collected the corals, designed the experiments, and edited the manuscript. JL conceived of the study, carried out the field work, and edited the manuscript. EC conceived of the study, designed the experiments, led the research cruise, and edited the manuscript.

\section{ACKNOWLEDGMENTS}

The authors wish to acknowledge Dana Russell and Adam Butler who helped in the set-up and tank maintenance, and Alex Barkman who helped in running the carbonic anhydrase assays. Thanks to Cheryl Morrison for conducting the microsattelite analysis of the coral collections. The authors are grateful for the support and efforts of the pilots of the DSV Alvin and the crew 
and officers of the R/V Atlantis who made this work possible. We also wish to acknowledge all of the support of the scientists on cruise AT26-14. Special thanks to Ivan Hürzeler and the rest of the Acid Horizon team for helping to spread the word. This research was supported by NSF BIO-OCE grant \#1220478. CEG was supported by the Fulbright-Colciencias scholarship program.

\section{REFERENCES}

Adkins, J. F., Boyle, E. A., Curry, W. B., and Lutringer, A. (2003). Stable isotopes in deep-sea corals and a new mechanism for "vital effects." Geochim. Cosmochim. Acta 67, 1129-1143. doi: 10.1016/S0016-7037(02)01203-6

Allemand, D., Furla, P., and Bénazet-Tambutté, S. (1998). Mechanisms of carbon acquisition for endosymbiont photosynthesis in Anthozoa. Can. J. Bot. 76, 925-941. doi: 10.1139/b98-086

Allemand, D., Tambutté, E., Zoccola, D., and Tambutté, S. (2011). "Coral calcification, cells to reefs," in Coral Reefs An Ecosystem in Transition, eds Z. Dubinsky and N. Stambler (Dordrecht: Springer), 119-150

Andersson, A. J., Mackenzie, F. T., and Bates, N. R. (2008). Life on the margin: implications of ocean acidification on Mg-calcite, high latitude and cold-water marine calcifiers. Mar. Ecol. Prog. Ser. 373, 265-273. doi: 10.3354/meps07639

Barshis, D. J., Ladner, J. T., Oliver, T. A., Seneca, F. O., Traylor-Knowles, N., and Palumbi, S. R. (2013). Genomic basis for coral resilience to climate change. Proc. Natl. Acad. Sci. U.S.A. 110, 1387-1392. doi: 10.1073/pnas.1210224110

Bertucci, A., Moya, A., Tambutté, S., Allemand, D., Supuran, C. T., and Zoccolo, D. (2013). Carbonic anhydrases in anthozoan corals - a review. Bioorgan. Med. Chem. 21, 1437-1450. doi: 10.1016/j.bmc.2012.10.024

Brooke, S., and Young, C. M. (2009). In situ measurement of survival and growth of Lophelia pertusa in the northern Gulf of Mexico. Mar. Ecol. Prog. Ser. 397, 153-161. doi: 10.3354/meps08344

Caldeira, K., and Wickett, M. E. (2003). Anthropogenic carbon and ocean pH. Nature 425, 365. doi: 10.1038/425365a

Calvo, E., Simó, R., Coma, R., Ribes, M., Pascual, J., Sabatés, A., et al. (2011). Effects of climate change on Mediterranean marine ecosystems: the case of the Catalan Sea. Clim. Res. 50, 1-29. doi: 10.3354/cr01040

Carreiro-Silva, M., Cerqueira, T., Godinho, A., Caetano, M., Santos, R. S., and Bettencourt, R. (2014). Molecular mechanisms underlying the physiological responses of the cold-water coral Desmophyllum dianthus to ocean acidification. Coral Reefs 33, 465-476. doi: 10.1007/s00338-014-1129-2

Cohen, A. L., and McConnaughey, T. A. (2003). Geochemical perspectives on coral mineralization. Rev. Mineral Geochem. 54, 151-187. doi: 10.2113/0540151

Cordes, E. E., McGinley, M. P., Podowski, E. L., Becker, E. L., Lessard-Pilon, S., Viada, S. T., et al. (2008). Coral communities of the deep Gulf of Mexico. Deep Sea Res. I 55, 777-787. doi: 10.1016/j.dsr.2008.03.005

Cripps, I. L., Munday, P. L., and McCormick, M. I. (2011). Ocean acidification affects prey detection by a predatory reef fish. PLoS ONE 6:e22736. doi: 10.1371/journal.pone.0022736

Davies, A. J., and Guinotte, J. M. (2011). Global habitat suitability for framework-forming cold-water corals. PLoS ONE 6:e18483. doi: 10.1371/journal.pone.0018483

Davies, P. S. (1989). Short-term growth measurement of corals using an accurate buoyant weighing technique. Mar. Biol. 101, 389-395. doi: $10.1007 /$ BF00428135

Dickson, A. G. (1990). Standard potential of the reaction: $\mathrm{AgCl}(\mathrm{s})+12 \mathrm{H} 2(\mathrm{~g})=$ $\mathrm{Ag}(\mathrm{s})+\mathrm{HCl}(\mathrm{aq})$, and and the standard acidity constant of the ion HSO4- in synthetic sea water from 273.15 to 318.15 K. J. Chem. Thermodyn. 22, 113-127. doi: 10.1016/0021-9614(90)90074-Z

Dickson, A. G., and Millero, F. J. (1987). A comparison of the equilibrium constants for the dissociation of carbonic acid in seawater media. Deep Sea Res. A Oceanogr. Res. Pap. 34, 1733-1743. doi: 10.1016/0198-0149(87)90021-5

Dickson, A. G., Sabine, C. L., and Christian, J. R. (2007). Guide to best Practices for Ocean $\mathrm{CO}_{2}$ Measurement, Vol. 3. Sidney, BC: PICES Spec Publiction.

Feely, R. A., Sabine, C. L., Lee, K., Berelson, W., Kleypas, J., Fabry, V. J., et al. (2004). Impact of anthropogenic $\mathrm{CO}_{2}$ on the $\mathrm{CaCO}_{3}$ system in the oceans. Science 305, 362-366. doi: 10.1126/science.1097329

Form, A. U., and Riebesell, U. (2012). Acclimation to ocean acidification during long-term $\mathrm{CO}_{2}$ exposure in the cold-water coral Lophelia pertusa. Glob. Chang. Biol. 18, 843-853. doi: 10.1111/j.1365-2486.2011.02583.x

Gattuso, J. P., Frankignoulle, M., Bourge, I., Romaine, S., and Buddemeir, R. W. (1998). Effect of calcium carbonate saturation of seawater on coral calcification. Glob. Planet. Change 18, 37-46. doi: 10.1016/S0921-8181(98)00035-6

Gaylord, B., Kroeker, K., and Sunday, J. (2014). Ocean acidification through the lens of ecological theory. Ecology 96, 3-15. doi: 10.1890/14-0802.1

Georgian, S. E., Deleo, D., Durkin, A., Gomez, C. E., Kurman, M., Lunden, J. J., et al. (2016a). Oceanographic patterns and carbonate chemistry in the vicinity of cold-water coral reefs in the Gulf of Mexico: implications for resilience in a changing ocean. Limnol. Oceanogr. 61, 648-665. doi: 10.1002/lno.10242

Georgian, S. E., Dupont, S., Kurman, M., Butler, A., Strömber, S., Larsson, A. I., et al. (2016b). Biogeographic variability in the physiological response of the cold-water coral Lophelia pertusa to ocean acidification. Mar. Ecol. 37, 1345-1359. doi: 10.1111/maec.12373

Georgian, S. E., Shedd, W., and Cordes, E. E. (2014). High-resolution ecological niche modelling of the cold-water coral Lophelia pertusa in the Gulf of Mexico. Mar. Ecol. Prog. Ser. 506, 145-161 doi: 10.3354/meps 10816

Goreau, T. F. (1959). The physiology of skeletons formation in corals. I. A method for measuring the rate of calcium deposition by corals under different conditions. Biol. Bull. 116, 59-75. doi: 10.2307/1539156

Gori, A., Ferrier-Pagès, C., Hennige, S. J., Murray, F., Rottier, C., Wicks, L. C., et al. (2016). Physiological response of the cold-water coral Desmophyllum diantus to thermal stress and ocean acidification. Peer J 4:e1606. doi: 10.7717/peerj.1606

Guinotte, J. M., Orr, J., Cairns, S., Freiwald, A., Morgan, L., and George, R. (2006). Will human-induced changes in seawater chemistry alter the distribution of deep-sea scleractinian corals? Front. Ecol. Environ. 4, 141-146. doi: 10.1890/1540-9295(2006)004[0141:WHCISC]2.0.CO;2

Hennige, S. J., Wicks, L. C., Kamenos, N. A., Perna, G., Findlay, H. S., and Robers, J. M. (2015). Hidden impacts of ocean acidification to live and dead coral framework. Proc. R Soc. B Biol. Sci. 282, 1-10. doi: 10.1098/rspb.2015.0990

Hoegh-Guldberg, O. (2014). Coral reef sustainability through adaptation: glimmer of hope or persistent mirage? Curr. Opin. Environ. Sustainability 7, 127-133. doi: 10.1016/j.cosust.2014.01.005

Hoegh-Guldberg, O., and Bruno, J. (2010). The impact of climate change on the World's marine ecosystems. Science 328, 1523-1528. doi: 10.1126/science.1189930

Holcomb, M., Venn, A. A., Tambutté, E., Tambutté, S., Allemand, D., Trotter, J., et al. (2014). Coral calcifying fluid $\mathrm{pH}$ dictates response to ocean acidification. Sci. Rep. 4:5207. doi: 10.1038/srep05207

IPCC (2013). Climate Change 2013: The Physical Science Basis. Contribution of the Working Group I to the Fiifth Assessment Report of the Intergovernmental Panel on Climate Change. Cambridge; New York, NY.

Jokiel, P., Maragos, J., and Franzisket, L. (1978). "Coral growth : buoyant weight technique," in Coral Reefs Research Methods, eds D. R. Stoddart and R. Johannes (Paris: UNESCO), 581.

Kaplan, E., and Maier, P. (1958). Non-parametric estimation from incomplete observations. J. Am. Stat. Assoc. 53, 457-481. doi: 10.1080/01621459.1958.10501452

Keeling, C. D., Bacastow, R. B., Bainbridge, A. E., Ekdahl, C. A., Guenther, P. R., Waterman, L. S., et al. (1976). Atmospheric carbon dioxide variations at Mauna Loa Observatory, Hawaii. Tellus A 28, 538-551. doi: 10.1111/j.2153-3490.1976.tb00701.x

Kelly, M. W., Padilla-Gamiño, J. L., and Hofmann, G. E. (2013). Natural variation and the capacity to adapt to ocean acidification in the keystone sea urchin Strongylocentrotus purpuratus. Global Change Biol. 19, 2536-2546. doi: $10.1111 /$ gcb.12251

Kleypas, J. A., and Langdon, C. (2006). "Coral reefs and changing seawater carbonate chemistry," in Coral Reefs Climte Change Science Management, eds J. T. Phinney, W. Skirving, J. Kleypas, and O. Hoegh-Guldberg (Washington, DC: American Geophysical Union), 73-110.

Kleypas, J. A., Buddemeier, R. W., Archer, D., Gattuso, J. P., Landgon, C., and Opdyke, B. N. (1999). Geochemical consequences of increased 
atmospheric carbon dioxide on coral reefs. Science 284, 118-120. doi: $10.1126 /$ science. 284.5411 .118

Kurihara, H. (2008). Effects of $\mathrm{CO}_{2}$-driven ocean acidification on the early developmental stages of invertebrates. Mar. Ecol. Prog. Ser. 373, 275-284. doi: $10.3354 /$ meps07802

Langdon, C., and Atkinson, M. J. (2005). Effect of elevated $\mathrm{pCO}_{2}$ on photosynthesis and calcification of corals and interactions with seasonal change in temperature/ irradiance and nutrient enrichment. J. Geophys. Res. C Ocean 110, 1-16. doi: 10.1029/2004JC002576

Langer, G., Nehrke, G., Probert, I., Ly, J., and Ziveri, P. (2009). Strain-specific responses of Emiliania huxleyi to changing seawater carbonate chemistry. Biogeosciences 6, 2637-2646. doi: 10.5194/bg-6-2637-2009

Larcom, E. A., McKean, D. L., Brooks, J. M., and Fisher, C. R. (2014). Growth rates, densities, and distribution of Lophelia pertusa on artificial structures in the Gulf of Mexico. Deep Sea Res. I 85, 101-109. doi: 10.1016/j.dsr.2013.12.005

Lartaud, F., Pareige, S., de Rafelis, M., Feuillassier, L., Bideau, M., Peru, E., et al. (2014). Temporal changes in the growth of two Mediterranean cold-water coral species, in situ and in aquaria. Deep Sea Res. II Top. Stud. Oceanogr. 99, 64-70. doi: 10.1016/j.dsr2.2013.06.024

Lee, K., Millero, F. J., Byrne, R. H., Feely, R. A., and Wanninkhof, R. (2000). The recommended dissociation constants for carbonic acid in seawater. Geophys. Res. Lett. 27, 229-232. doi: 10.1029/1999GL002345

Lohbeck, K. T., Riebesell, U., and Reusch, T. B. H. (2012). Adaptive evolution of a key phytoplankton species to ocean acidification. Nat. Geosci. 5, 346-351. doi: 10.1038/ngeo1441

Lunden, J. J., Georgian, S. E., and Cordes, E. E. (2013). Aragonite saturation states at cold-water coral reefs structured by Lophelia pertusa in the northern Gulf of Mexico. Limnol. Oceanogr. 58, 354-362. doi: 10.4319/lo.2013.58.1.0354

Lunden, J. J., McNicholl, C. G., Sears, C. R., Morrison, C. L., and Cordes, E. E. (2014a). Acute survivorship of the deep-sea coral Lophelia pertusa from the Gulf of Mexico under acidification, warming, and deoxygenation. Front. Mar. Sci. 1, 1-12. doi: 10.3389/fmars.2014.00078

Lunden, J. J., Turner, J. M., Mcnicholl, C. G., Glynn, C. K., and Cordes, E. E. (2014b). Design, development, and implementation of recirculating aquaria for maintenance and experimentation of deep-sea corals and associated fauna. Limnol. Oceanogr. Methods 12, 363-372. doi: 10.4319/lom.2014.12.363

Maier, C., Hegeman, J., Weinbauer, M. G., and Gattuso, J.-P. (2009). Calcification of the cold-water coral Lophelia pertusa, under ambient and reduced $\mathrm{pH}$. Biogeosciences 6, 1671-1680. doi: 10.5194/bg-6-1671-2009

Maier, C., Popp, P., Sollfrank, N., Weinbauer, M. G., Wild, C., and Gattuso, J.-P. (2016). Effects of elevated $\mathrm{pCO}_{2}$ and feeding on net calcification and energy budget of the Mediterranean cold-water coral Madrepora oculata. J. Exp. Biol. 219, 3208-3217. doi: 10.1242/jeb.127159

Maier, C., Schubert, A., Berzunza Sánchez, M. M., Weinbauer, M., Watremez, P., Gattuso, J.-P., et al. (2013). End of the Century $\mathrm{pCO}_{2}$ levels do not impact calcification in mediterranean cold-water corals. PLoS ONE 6:e62655. doi: 10.1371/journal.pone.0062655

Maier, C., Watremez, P., Taviani, M., Weinbaur, M. G., and Gattuso, J.-P. (2012). Calcification rates and the effect of ocean acidification on Mediterranean cold-water corals. Proc. R Soc. B Biol. Sci. 279, 1716-1723. doi: $10.1098 /$ rspb.2011.1763

McCulloch, M., Trotter, J., Montagna, P., Falter, J., Dunbar, R., Freiwald, A., et al. (2012). Resilience of cold-water scleractinian corals to ocean acidification: Boron isotopic systematics of $\mathrm{pH}$ and saturation state up-regulation. Geochim. Cosmochim. Acta 87, 21-34. doi: 10.1016/j.gca.2012.03.027

Mehrbach, C., Culberson, C. H., Hawley, J. E., and Pytkowicz, R. (1973). Measurement of the Apparent Dissociation Constants of Carbonic Acid in Seawater at Atmospheric Pressure. Limnol. Oceanogr. 18, 897-907. doi: 10.4319/lo.1973.18.6.0897

Morrison, C. L., Eackles, M. S., Johnson, R. L., and King, T. L. (2008). Characterization of 13 microsatellite loci for the deep-sea coral, Lophelia pertusa (Linnaeus 1758), from the western North Atlantic Ocean and Gulf of Mexico. Mol. Ecol. Resour. 8, 1037-1039. doi: 10.1111/j.1755-0998.2008.02147.x

Morrison, C. L., Ross, S. W., Nizinski, M. S., Brooke, S., Järnegren, J., Waller, R. G., et al. (2011). Genetic discontinuity among regional populations of Lophelia pertusa in the North Atlantic Ocean. Conserv. Genet. 12, 713-729. doi: 10.1007/s10592-010-0178-5
Movilla, J., Gori, A., Calvo, E., Gori, A., López-Sanz, À., Grinyó J., et al. (2014). Resistance of two mediterranean cold-water coral species to low-pH conditions. Water 6, 59-67. doi: 10.3390/w6010059

Moya, A., Huisman, L., Ball, E. E., Hayward, D. C., Grasso, L. C., Chua, C. M., et al. (2012). Whole transcriptome analysis of the coral Acropora millepora reveals complex responses to $\mathrm{CO}_{2}$-driven acidification during the initiation of calcification. Mol. Ecol. 21, 2440-2454. doi: 10.1111/j.1365-294X.2012.05554.x

Moya, A., Tambutté, S., Bertucci, A., Tambutté, E., Lotto, S., Vullo, D., et al. (2008). Carbonic anhydrase in the scleractinian coral Stylophora pistillata: characterization, localization, and role in biomineralization. J. Biol. Chem. 283, 25475-25484. doi: 10.1074/jbc.M804726200

Mueller, C. E., Lundälv, T., Middelburg, J. J., and van Oevelen, D. (2013). The symbiosis between Lophelia pertusa and Eunice norvegica stimulates coral calcification and worm assimilation. PLOS ONE 8, 1-9. doi: 10.1371/journal.pone.0058660

Orr, J. C., Fabry, V. J., Aumont, O., Bopp, L., Doney, S. C., Feely, R. A., et al. (2005). Anthropogenic ocean acidification over the twenty-first century and its impact on calcifying organisms. Nature 437, 681-686. doi: 10.1038/nature04095

Palumbi, S. R., and Sotka, E. E. (2006). The use of genetic clines to estimate dispersal distances of marine larvae. Ecology 87, 1094-1103 doi: 10.1890/0012-9658(2006)87[1094:TUOGCT]2.0.CO;2

Pančić, M., Hansen, P. J., Tammilehto, A., and Lundholm, N. (2015). Resilience to temperature and $\mathrm{pH}$ changes in a future climate change scenario in six strains of the polar diatom Fragilariopsis cylindrus. Biogeosciences 12, 4235-4244. doi: 10.5194/bg-12-4235-2015

Parker, L. M., Ross, P. M., and O'Connor, W. A. (2011). Populations of the Sydney rock oyster, Saccostrea glomerata, vary in response to ocean acidification. Mar. Biol. 158, 689-697. doi: 10.1007/s00227-010-1592-4

Parker, L. M., Ross, P. M., O’Connor, W. A., Borysko, L., Raftos, D. A., and Pörtner, H.-O. (2012). Adult exposure influences offspring response to ocean acidification in oysters. Glob. Change Biol. 18, 82-92. doi: 10.1111/j.1365-2486.2011.02520.x

Parmesan, C., and Yohe, G. (2003). A globally coherent fingerprint of climate change impacts across natural systems. Nature 421:37. doi: $10.1038 /$ nature 01286

Pespeni, M. H., Sanford, E., Gaylord, B., Hill, T. M., Hosfelt, J. D., Jaris, H. K., et al. (2013). Evolutionary change during experimental ocean acidification. Proc. Natl. Acad. Sci. U.S.A. 110, 6937-6942. doi: 10.1073/pnas.1220673110

Pistevos, J. C. A., Calosi, P., Widdicombe, S., and Bishop, J. D. D. (2011) Will variation among genetic individuals influence species responses to global climate change? Oikos 120, 675-689. doi: 10.1111/j.1600-0706.2010. 19470x

Pörtner, H. O., Langenbuch, M., and Reipschläger, A. (2004). Biological impact of elevated ocean $\mathrm{CO}_{2}$ concentrations: lessons from animal physiology and earth history. J. Oceanogr. 60, 705-718. doi: 10.1007/s10872-004-5763-0

Quinn, G. P., and Keough, M. J. (2002). Experimental Design and Data Analysis for Biologist. New York, NY: Cambridge University Press.

Robbins, L. L., Hansen, M. E., Kleypas, J. A., and Meylan, S. C. (2010). CO 2 calc a User-Friendly Seawater Carbon Calculator for Windows, Mac OS X and iOS (iPhone). US Geological Survey Open-File Report 2010-1280 17.

Roberts, J. M., Wheeler, A. J., and Freiwald, A. (2006). Reefs of the deep: the biology and geology of cold-water coral ecosystems. Science 312, 543-547. doi: 10.1126/science.1119861

Rodolfo-Metalpa, R., Montagna, P., Aliani, S., Borghini, M., Canese, S., HallSpencer, J., et al. (2015). Calcification is not the Achilles' heel of coldwater corals in an acidifying ocean. Glob. Chang. Biol. 21, 2238-2248. doi: $10.1111 /$ gcb. 12867

Rodrigues, L. J., and Grottoli, A. G. (2007). Energy reserves and metabolism as indicators of coral recovery from bleaching. Limnol. Oceanogr. 52, 1874-1882. doi: $10.4319 /$ lo.2007.52.5.1874

Rogers, A. D. (1999). The Biology of Lophelia pertusa (Linnaeus 1758) and Other Deep-Water Reef-Forming Corals and Impacts from Human Activities. Int. Rev. Hydrobiol. 84, 315-406. doi: 10.1002/iroh.199900032

Sabine, C. L., Feely, R. A., Gruber, N., Key, R. M., Lee, K., Bullister, J. L., et al. (2004). The oceanic sink for anthropogenic $\mathrm{CO}_{2}$. Science 305, 367-371. doi: $10.1126 /$ science. 1097403

Schmider, E., Ziegler, M., Danay, E., Beyer, L., and Bühner, M. (2010). Is it really robust? Reinvestigating the robustness of ANOVA against violations of the 
normal distribution assumption. Methodol. Eur. J. Res. Methods Behav. Soc. Sci. 6, 147-151. doi: 10.1027/1614-2241/a000016

Schoepf, V., Grottoli, A. G., Warner, M. E., Cai, W. J., Melman, T. F., Hoadley, K. D., et al. (2013). Coral energy reserves and calcification in a high- $\mathrm{CO}_{2}$ world at two temperatures. PLoS ONE 8:e75049. doi: 10.1371/journal.pone.00 75049

Soetaert, K., Mohn, C., Rengstorf, A., Grehan, A., and van Oevelen, D. (2016). Ecosystem engineering creates a direct nutritional link between 600-m deep cold-water coral mounds and surface productivity. Sci. Rep. 6:35057. doi: $10.1038 /$ srep35057

Strømgren, T. (1971). Vertical and horizontal distribution of Lophelia pertusa (Linné) in Trondheimsfjorden on the west coast of Norway. Det Kongelige Norske Videnskabers Selskabs Skrifter $6,1-9$.

Sunday, J. M., Crim, R. N., Harley, C. D. G., and Hart, M. W. (2011). Quantifying rates of evolutionary adaptation in response to ocean acidification. PLoS ONE 6:e22881. doi: 10.1371/journal.pone.00 22881

Tambutté, S., Tambutté, E., Zoccola, D., Caminiti, N., Lotto, S., Moya, A., et al. (2007). Characterization and role of carbonic anhydrase in the calcification process of the azooxanthellate coral Tubastrea aurea. Mar. Biol. 151, 71-83. doi: 10.1007/s00227-006-0452-8

Vargas, C. A., Lagos, N. A., Lardies, M. A., Duarte, C., Manríguez, P. H., Aguilera, C., et al. (2017). Species-specific responses to ocean acidification should account for local adaptation and adaptive plasticity. Nat. Ecol. Evol. 1:0084. doi: 10.1038/ s41559-017-0084
Venn, A. A., Tambutté, E., Holcomb, M., Laurent, J., Allemand, D., and Tambutté, S. (2013). Impact of seawater acidification on $\mathrm{pH}$ at the tissue-skeleton interface and calcification in reef corals. Proc. Natl. Acad. Sci. U.S.A. 110, 1634-1639. doi: 10.1073/pnas.1216153110

Wall, M., Ragazzola, F., Foster, L. C., Form, A., and Schmidt, D. N. (2015). pH upregulation as a potential mechanism for the cold-water coral Lophelia pertusa to sustain growth in aragonite undersaturated conditions. Biogeosciences 12, 6869-6880. doi: 10.5194/bg-12-6869-2015

Waller, R. G., and Tyler, P. A. (2005). The reproductive biology of two deep-water, reef-building scleractinians from the NE Atlantic Ocean. Coral Reefs 24:514. doi: 10.1007/s00338-005-0501-7

Weis, V. M., Smith, G. J., and Muscatine, L. (1989). CO 2 supply mechanisms in zooxanthellate cnidarians: role of carbonic anhydrase. Mar. Biol. 100, 195-202. doi: $10.1007 / \mathrm{BF} 00391958$

Conflict of Interest Statement: The authors declare that the research was conducted in the absence of any commercial or financial relationships that could be construed as a potential conflict of interest.

Copyright (C) 2017 Kurman, Gómez, Georgian, Lunden and Cordes. This is an openaccess article distributed under the terms of the Creative Commons Attribution License (CC BY). The use, distribution or reproduction in other forums is permitted, provided the original author(s) or licensor are credited and that the original publication in this journal is cited, in accordance with accepted academic practice. No use, distribution or reproduction is permitted which does not comply with these terms. 